\title{
TOPICAL ISSUES IN THE STUDY OF THE EARLY AENEOLITHIC OF THE DON FOREST-STEPPE (CHRONOLOGY, PERIODIZATION, SYNCHRONIZATION)
}

(C) 2019

Skorobogatov Andrey Mikhailovich, candidate of historical sciences, head of Archeological Department LLC «Terra» (Voronezh, Russian Federation)

Abstract. For a long time, the Eneolithic of the Don forest-steppe remained one of the least studied epochs in the archaeological scheme of the region. However, since the late 1960s, sites with materials of the Eneolithic have been actively explored on the territory of the Voronezh and Lipetsk Regions. By the 1980s, researchers had a concept for the development of copper-stone age cultures within the system of the Mariupol cultural-historical region of the Dnieper-Don-Ural interfluve, which is still relevant today. The criteria for distinguishing the Eneolithic era in the steppe and forest-steppe spaces of the East European steppe and forest-steppe were substantiated. The idea of their synchronization with complexes of the Tripolye A period was designated. The early Eneolithic in the Don foreststeppe was marked by the appearance of a population with specific ceramics of Nizhnedonskaya culture. Questions of the chronology of the early Eneolithic were solved exclusively by methods of analogies with the materials of neighboring territories and synchronization with the local Neolithic complexes. The paper deals with the problems of chronology, periodization and synchronization of materials from the early Aeneolithic of the territory of the Don forest-steppe. The focus is on the absolute dating of the Nizhnedonskaya culture of the Mariupol cultural-historical region and its synchronization with the early Tripolye Culture. According to all the data available to date, the region's early Eneolithic can be dated from 5300 to 4250 BC.

Keywords: Don forest-steppe; Middle Don; Upper Don; Voronezh Region; Lipetsk Region; early Eneolithic; Mariupol cultural-historical region; Nizhnedonskaya Culture; ceramics; copper; ground burial grounds; burials; early Tripolye Culture; radiocarbon dates; synchronization; periodization; chronology.

УДК $902.01,903$

DOI 10.24411/2309-4370-2019-12218

Статья поступила в редакцию 11.02.2019

\section{МАТЕРИАЛЫ РАННЕГО НЕОЛИТА СТОЯНКИ ЯРЛУКОВСКАЯ ПРОТОКА (ПУНКТ 222) НА ВЕРХНЕМ ДОНУ}

(C) 2019

Смольянинов Роман Викторович, кандидат исторических наук, заведующий кабинетом археологии и этнологии

Липеикий государственный педагогический университет имени П.П. Семенова-Тян-Шанского

(2. Липеик, Российская Федерация)

Куличков Алексей Александрович, заведующий отделом краеведческой работы Межпоселенческий координационно-методический иентр

Грязинского мунищипального района Липецикой области (2. Грязи, Липецฺкая область, Российская Федерация)

Юркина Елизавета Сергеевна, студент института истории, права и общественных наук

Липеикий государственный педагогический университет имени П.П. Семенова-Тян-Шанского

(2. Липецк, Российская Федерация)

Аннотация. В данной статье анализируются материалы расположенной в пойме реки Матыра (левый приток р. Воронеж) стоянки Ярлуковская протока (пункт 222) в Грязинском районе Липецкой области. Она исследовалась в 1963, 1964, 1967 и 1968 годах В.П. Левенком. Здесь были выявлены материалы трех ранненеолитических культур VI тыс. до н.э. Материалы елшанской культуры представлены венчиками и днищами от 12 сосудов. Почти вся посуда, кроме одного днища и нескольких стенок, без орнамента, за исключением одного или двух линий ямок. Вся керамика хорошо заглажена, для изготовления всех сосудов использовалась илистая глина. Условия расположения материалов в культурном слое подтверждают более раннее залегание керамики елшанской культуры. Керамика карамышевской культуры представлена фрагментами от трёх сосудов. Посуда преимущественно украшена мелкими овальными наколами, составленными в горизонтальные и косовертикальные ряды. Керамика лепилась из илистой глины. Посуда среднедонской культуры представлена венчиками и округлой формы днищами от 15 сосудов. Она украшена треугольными наколами или мелкими гребенчатыми отпечатками. Керамика лепилась из илистой глины. Изделия из камня представлены 304 единицами, преимущественно из кремня. Каменная индустрия может быть охарактеризована как отщеповопластинчатая. Памятник является в некоторой степени смешанным комплексом, поэтому чётких стратиграфических и планиграфических наблюдений залегания каменного инвентаря сделать не удалось.

Ключевые слова: Верхний Дон; лесостепь; ранний неолит; керамика; примесь; радиоуглеродное датирование; кремень; кварцит; среднедонская неолитическая культура; карамышевская неолитическая культура; елшанская неолитическая культура; накол; гребенчатый орнамент; орудие; отщеп; скребок; нож; многофункциональное орудие; пластина; нуклеус; типологический анализ.

Стоянка Ярлуковская Протока (пункт 222) (рис. 1: 1) была выявлена в 1963 г. В.П. Левенком в итоге исследований Верхне-Донской археологической экспе- диции Ленинградского отделения ИА АН СССР в ходе работ по сбору данных для археологической карты Липецкой области [1]. 

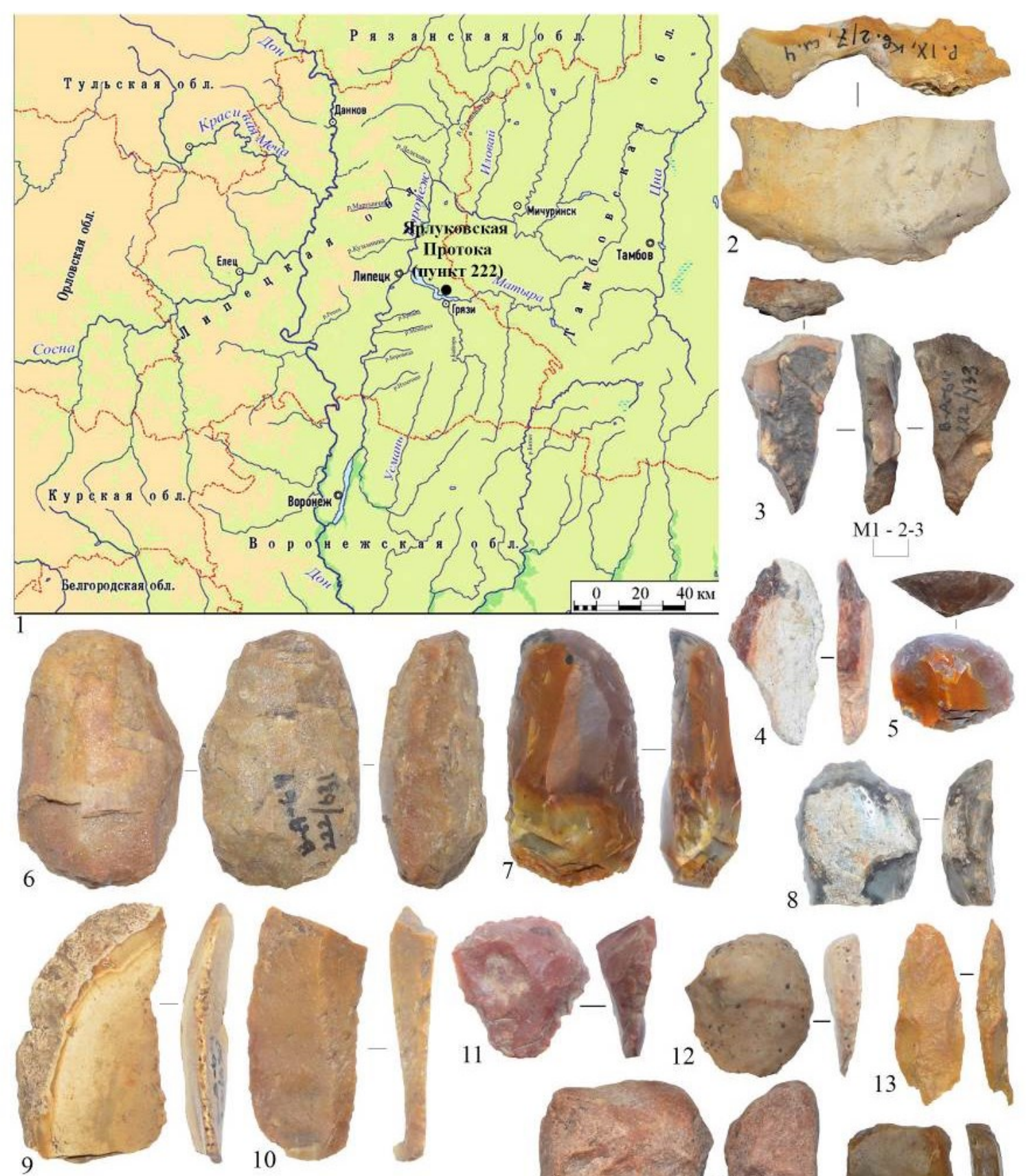

8
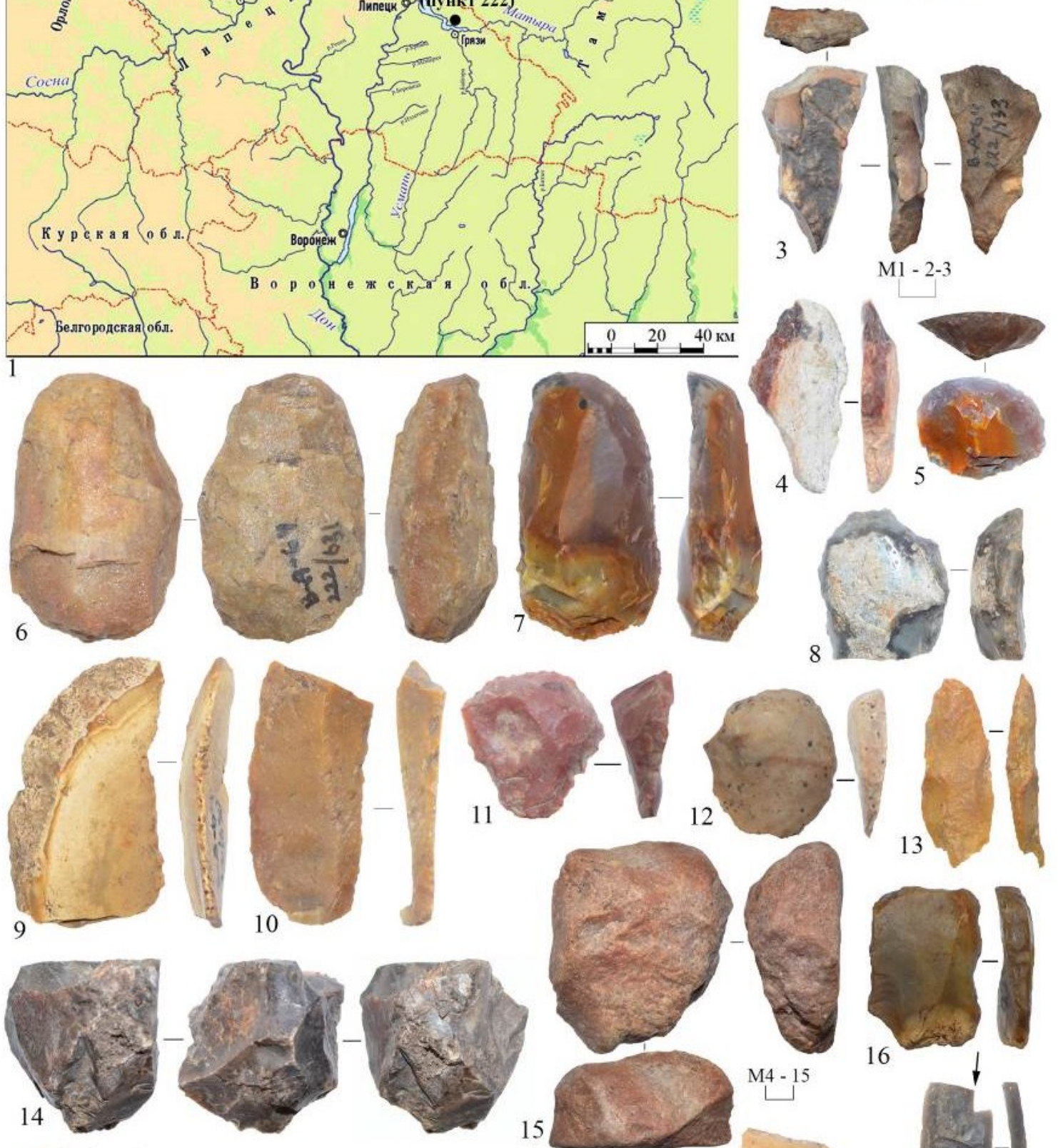

12
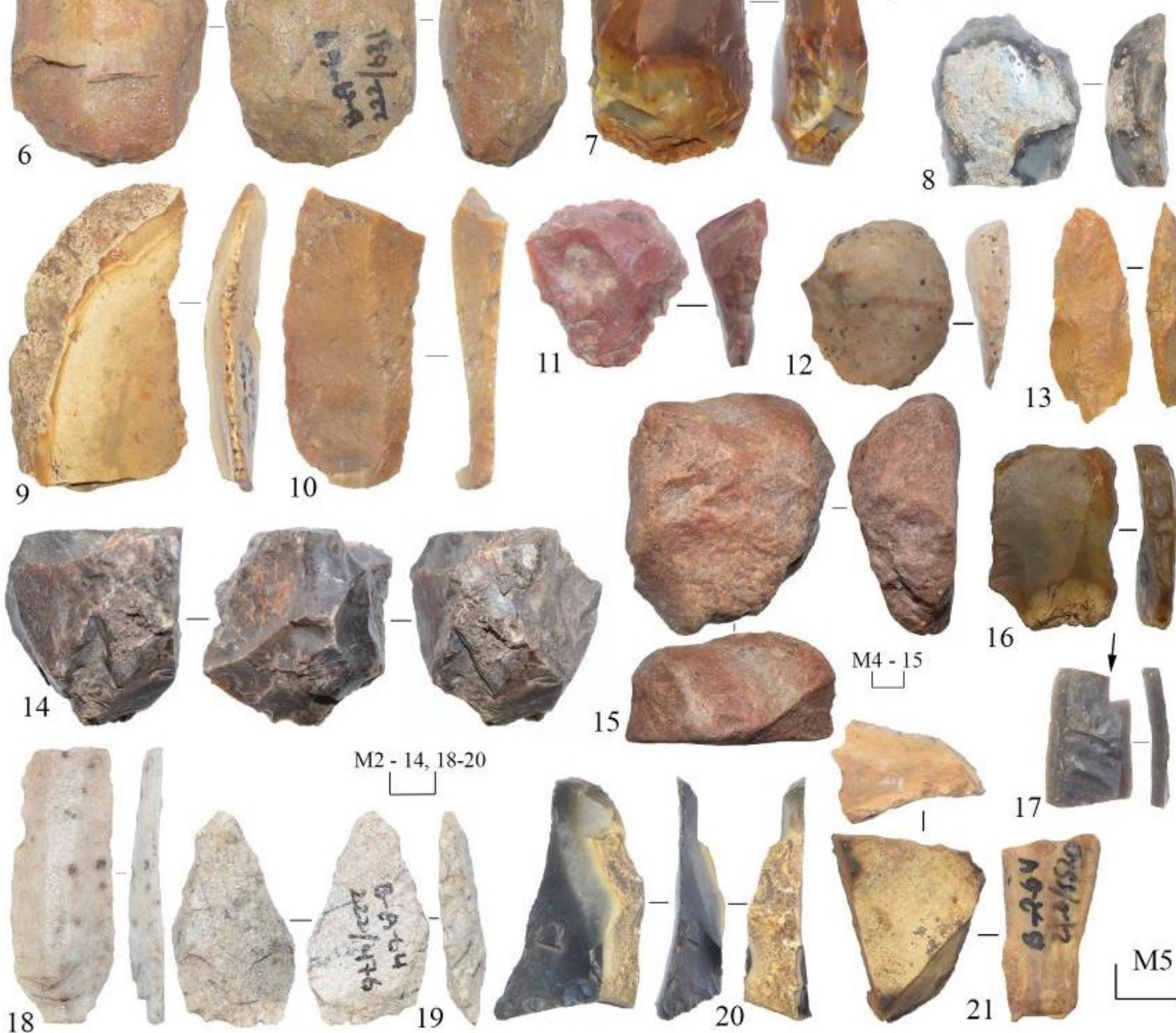

13
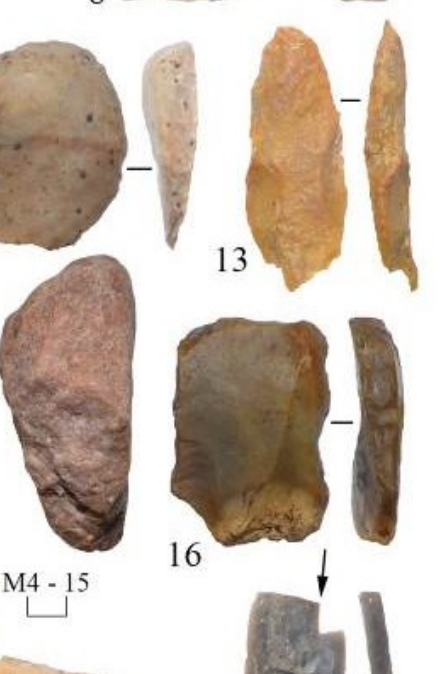

16
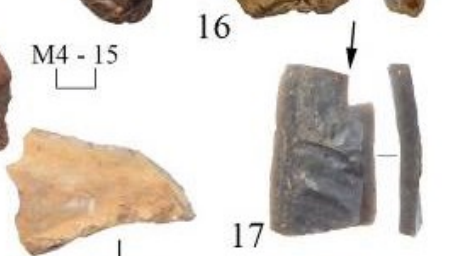

17
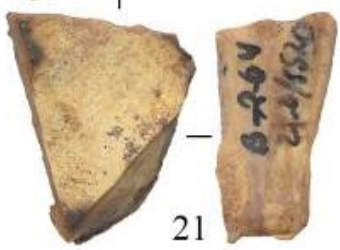

M5

Рисунок 1 - стоянка Ярлуковская Протока (пункт 222).

1 - местоположение памятника на карте Центрального Черноземья; 2-21 - каменный инвентарь

С 1964 г. исследования в верховьях р. Матыра приобретают охранный характер в связи с затоплением поймы и созданием Матырского водохранили- ща для нужд Новолипецкого металлургического завода. В этом году начаты раскопки стояки Ярлуков-

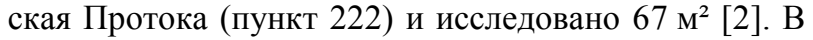


1967 г. раскопано ещё 127 м² памятника [3]. В 1968 г. Верхне-Донская новостроечная экспедиция под общим руководством В.П. Левенка имеет в своем составе несколько действующих одновременно отрядов. За этот год на памятнике изучено $208 \mathrm{~m}^{2}$ [4]. Таким образом, за три года раскопочных исследований на стоянке В.П. Левенком было исследовано $402 \mathrm{M}^{2}$.

К сожалению, материалы с изученной В.П. Левенком стоянки почти не были введены в научный оборот. Они использовались им при защите кандидатской диссертации [5], и публиковались только единичные артефакты [6-8].

На территории Верхнего Дона известно множество ранненеолитических памятников. Из них по четыре местонахождения принадлежат к елшанской и верхневолжской культурам [9; 10], 72 памятника с керамикой украшенной преимущественно наколами треугольной формы относятся к среднедонской культуре. Керамических комплексов с карамышевской ранненеолитической культуры известно 26 стоянок. Практически все они располагаются на берегах рек Воронеж и Дон на низко расположенных пойменных останцах террас [11].

Материалы трёх из четырёх вышеназванных ранненеолитических культур получены в нижних слоях на исследуемом В.П. Левенком поселении в 1963, 1964, 1967 и 1968 годах. Памятник находился в пойме р. Матыра (левый приток р. Воронеж, левый приток р. Дон). Сейчас он затоплен водохранилищем.

Выделение технологической информации о керамическом производстве ранненеолитических материалов производилось при помощи бинокулярного микроскопа. Информация получена по методическим рекомендациям, разработанным А.А. Бобринским [12] в рамках историко-культурного подхода. Им была выделена структура гончарного производства, состоящая из десяти обязательных и двух дополнительных ступеней, объединённых в свою очередь, в три стадии: подготовительную, созидательную и закрепительную [13, с. 9-11].

\section{Елшанская культура \\ (рубеж VII-VI тыс. до н.э.)}

В.П. Левенок разделил культурный слой стоянки на относительные горизонты (по $20 \mathrm{~cm}$ каждый). Всего их было выделено семь. В двух нижних им обнаружено три профилированных венчика (рис. 2: 7, 10, 11), один закрытый (рис. 2: 2) и восемь от прямостенных или же яйцевидных (рис. 2: 1, 3-6, 8, 9, $17)$ сосудов. По характеру оформления среза венчики распределяются в одном случае на плоские (рис. 2: 2), в двух - чуть приострённые (рис. 2: 6, 9), а в остальных - с округлым краем. Выявлено два днища, первое - приострённое и без орнамента (рис. 2: 19), второе было плоским при этом орнаментировано мелкими наколами овальной формы (рис. 2: 18). В этом же горизонте обнаружен обломок керамического лощила или скребка (рис. 2: 20). Следует отметить, что все фрагменты, исключая одно днище и несколько стенок (рис. 2: 14) не орнаментированы. Керамика украшена по верху сосудов одним (рис. 2: 1, $5,6,8,9,11)$ или двумя рядами овальных ямок (рис. 2: 2, 7, 10, 13).

Вся выявленная елшанская керамика на данном памятнике хорошо заглажена, толщина её стенок 79 мм. Мы проанализировали фрагменты от 12 сосудов, найденных на данном поселении и относимых к елшанской культуре. Исходным пластическим сырь- ем (далее ИПС) для лепки всех горшков была илистая глина. Все они изготовлялись из ожелезнённого сырья. При дополнительном дожигании в муфельной печи фрагменты получали кирпично-красный (2 обр.) или оранжевый (10 обр.) цвета. Во всей керамике в малозначительной концентрации выявлены органические включения в виде полостей от выгоревших растений и водорослей (рис. 7: 1, 3). Керамическое сырьё чаще сильно, гораздо реже среднезапесоченное. Песок в ИПС кварцевый окатанный размером 0,2-0,4 мм, в единичной концентрации обнаружены песчинки размером до 1 мм (рис. 7: 1-3). Сырьё всех елшанских горшков использовалось в естественном увлажнённом состоянии, следов дробления не зафиксировано.

В связи с фрагментированностью материала нам удалось обнаружить лишь общие признаки конструирования сосудов. Керамика была изготовлена способом скульптурной лепки из небольших лоскутков размером от $1 \times 1,1,5 \times 1,5$ до $2 \times 2$ см, которые накладывались по траектории близкой к спиралевидной. Выявлено три способа обработки поверхностей: 1 - обе поверхности тщательно заглажены грубо выделанной кожей (5 обр.); 2 - обе поверхности расчёсаны жёстким гребенчатым штампом (2 обр.); 3 внешняя тщательно заглажена грубо выделанной кожей, а внутренняя расчёсана жёстким гребенчатым штампом (5 обр.).

При изготовлении данной керамики мы можем предположить использование кострового обжига. Стоить отметь непродолжительную выдержку при температурах каления $650-700^{\circ} \mathrm{C}$, и равномерное повышение и дальнейшее снижение температур, что сказалось на однородной толщине слоёв.

\section{Карамышевская культура}

(1 половина VI тыс. до н.э.)

На памятнике выявлены фрагменты трёх сосудов карамышевской культуры (рис. 3: 1-4). По форме они распределяются на закрытые яйцевидные (рис. 2: 1), закрытые S-видные и прямостенные сосуды. Cрезы венчиков приострённые и округлые. Керамика украшена овальными наколами, составленными в горизонтальные и косовертикальные (рис. 3: 2) ряды. Керамика тонкостенная, поверхности залощены. Технология изготовления и ИПС близки вышеописанной елшанской посуде.

Среднедонская культура (VI mыс. до н.э.)

На памятнике обнаружена керамика среднедонской культуры двух видов. Она декорирована накольчатым орнаментом и представлена 19 венчиками от 11 сосудов (рис. 4, 5). Посуда коричневого цвета, толщиной 6-9 мм. Горшки разделялись на прямостенные (рис. 4: 4, 12), закрытые (рис. 4: 2), слегка закрытой яйцевидной формы (рис. 4: 1, 3, 9), и профилированные (рис. 4: 5-8, 11). Срезы венчиков округлые, в одном случае он прямой (рис. 4: 1). На большинстве сосудов по их краю нанесена горизонтальная линия жемчужных (рис. 4: 6) или ямочных вдавлений с коническим дном (рис. 4: 2, 3, 5, 7-9, 11, 12). В своем большинстве посуда украшена треугольными насечками и наколами (рис. 4: 2-5, 7, 11, 13) составленными в горизонтальный ряд. А также она орнаментировалась косовертикальными рядами, поставленных в строчку раздельных треугольных наколов и скобок (рис. 4: 1, 6, 8, 9, 12). Часть поверхности сосудов не украшалась. Выявлен один фрагмент приострённого днища без орнамента (рис. 4: 10). 


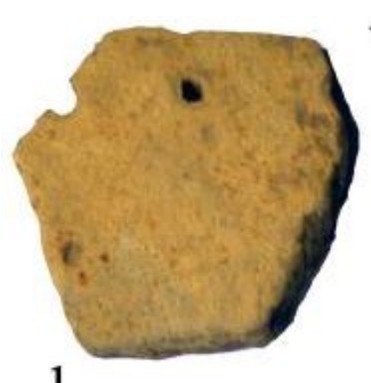

1

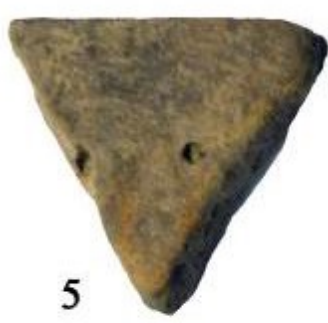

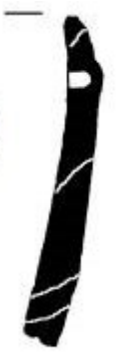

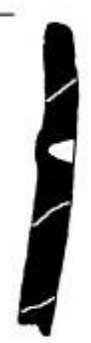

2
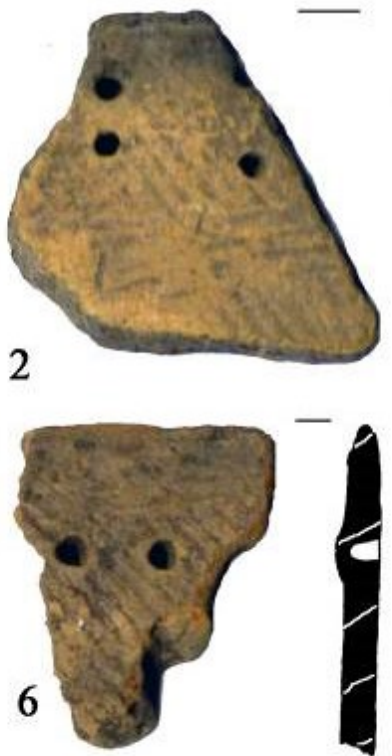

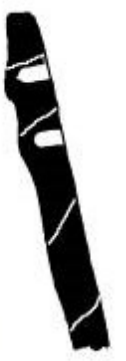

4

3

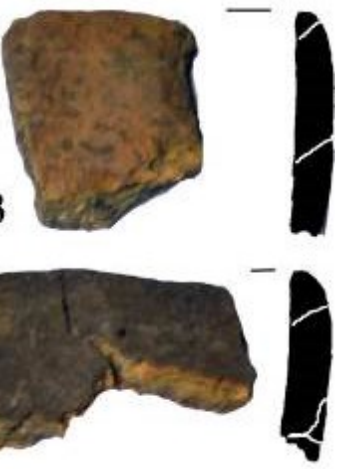

7

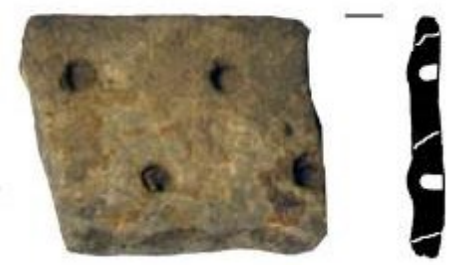

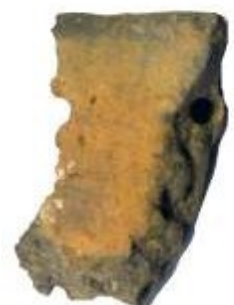

8

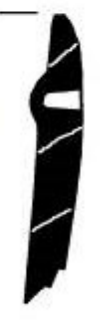

9
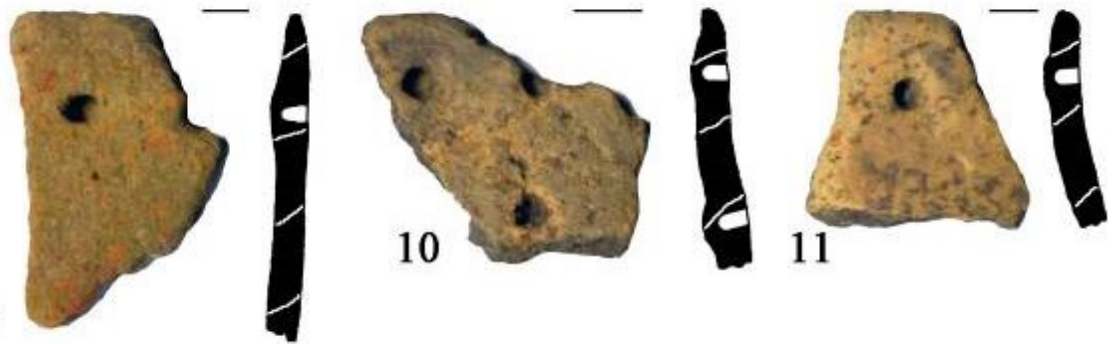

11
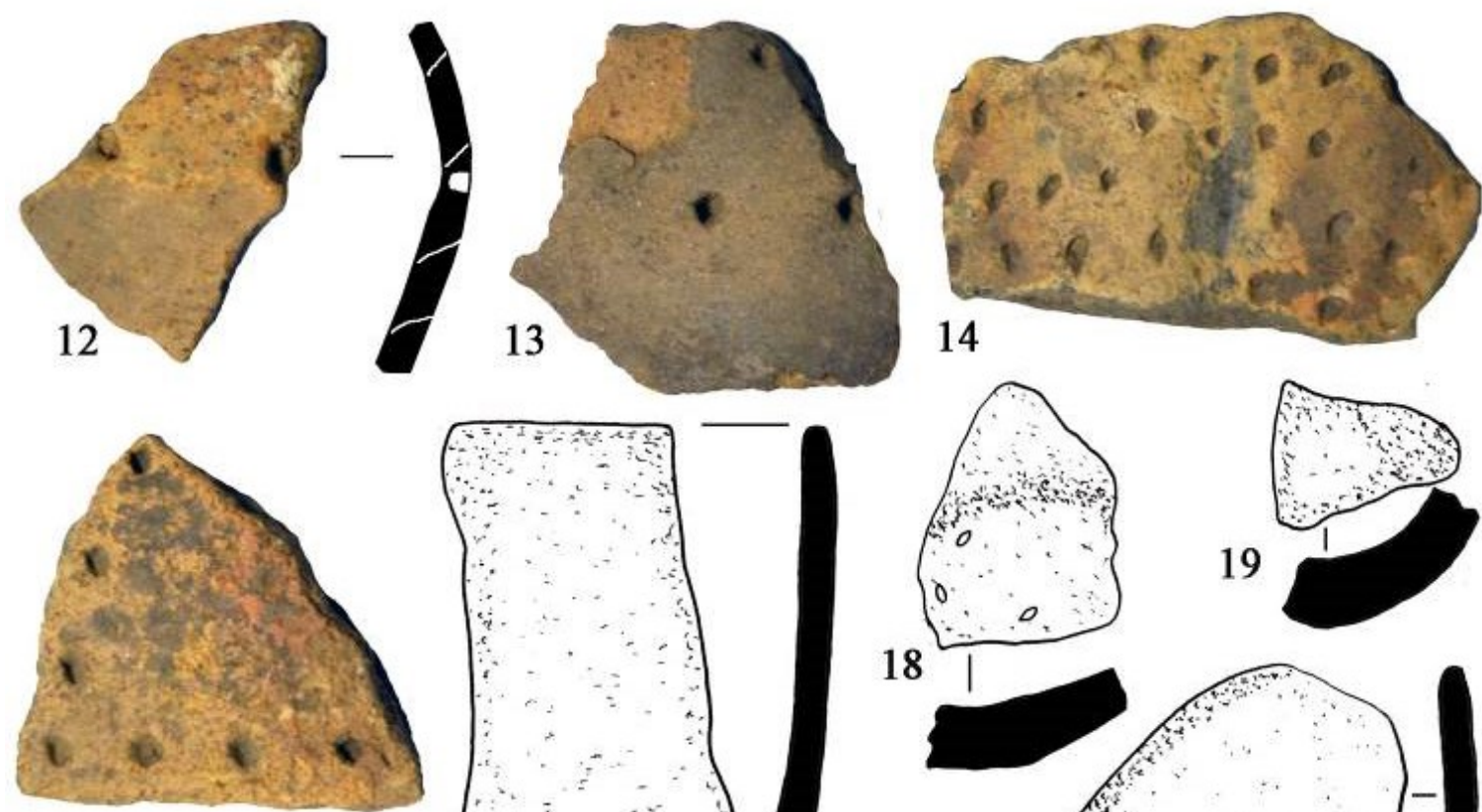

16
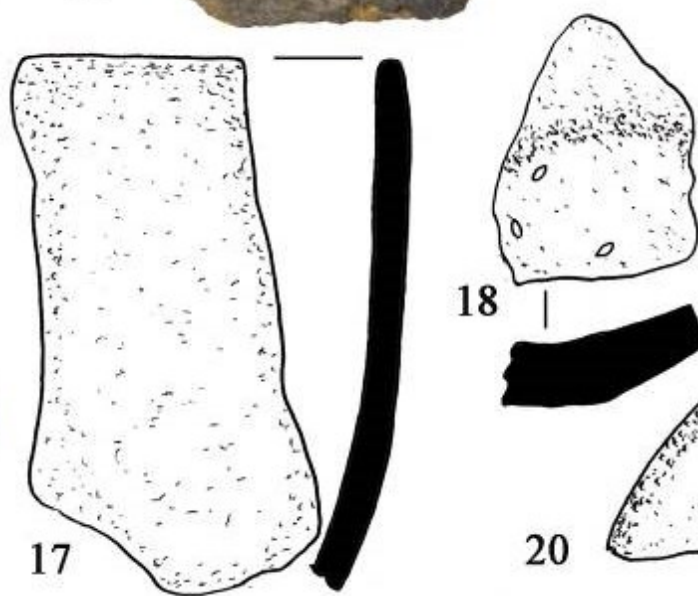

19

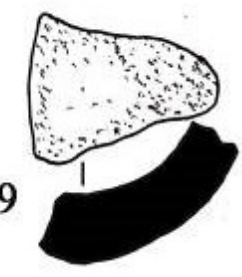

18

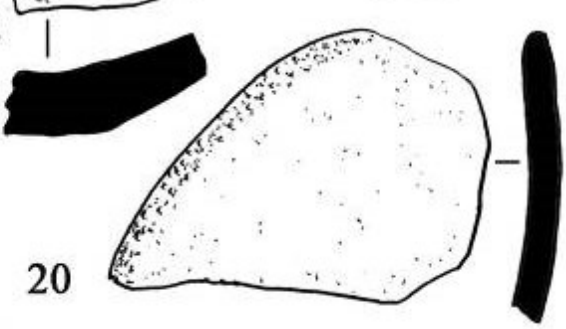

Рисунок 2 - Стоянка Ярлуковская Протока (пункт 222). 1-20- керамика елшанской культуры

Гребенчатая керамика среднедонской культуры с этого поселения представлена фрагментами от 4-5 горшков (рис. 6). Она также относится к среднедонской культуре и содержит подобной формы горшки, произведённые также, что и вышеописанная керамика, украшенная треугольными наколами. Отмечено два ребра горшков, говорящих о биконичности некоторых сосудов (рис. 6: 7, 15). Одно выявленное дни- ще также от горшка с приострённым днищем. Орнаментальные композиции гребенчатого штампа повторяют композиции выполненные наколом.

Интересна также находка керамического скребка из стенки сосуда, орнаментированного гребенчатыми отпечатками (рис. 6: 13), и глиняного шарика - игрушки, украшенного рядами гребенчатых насечек (рис. 3: 5). 

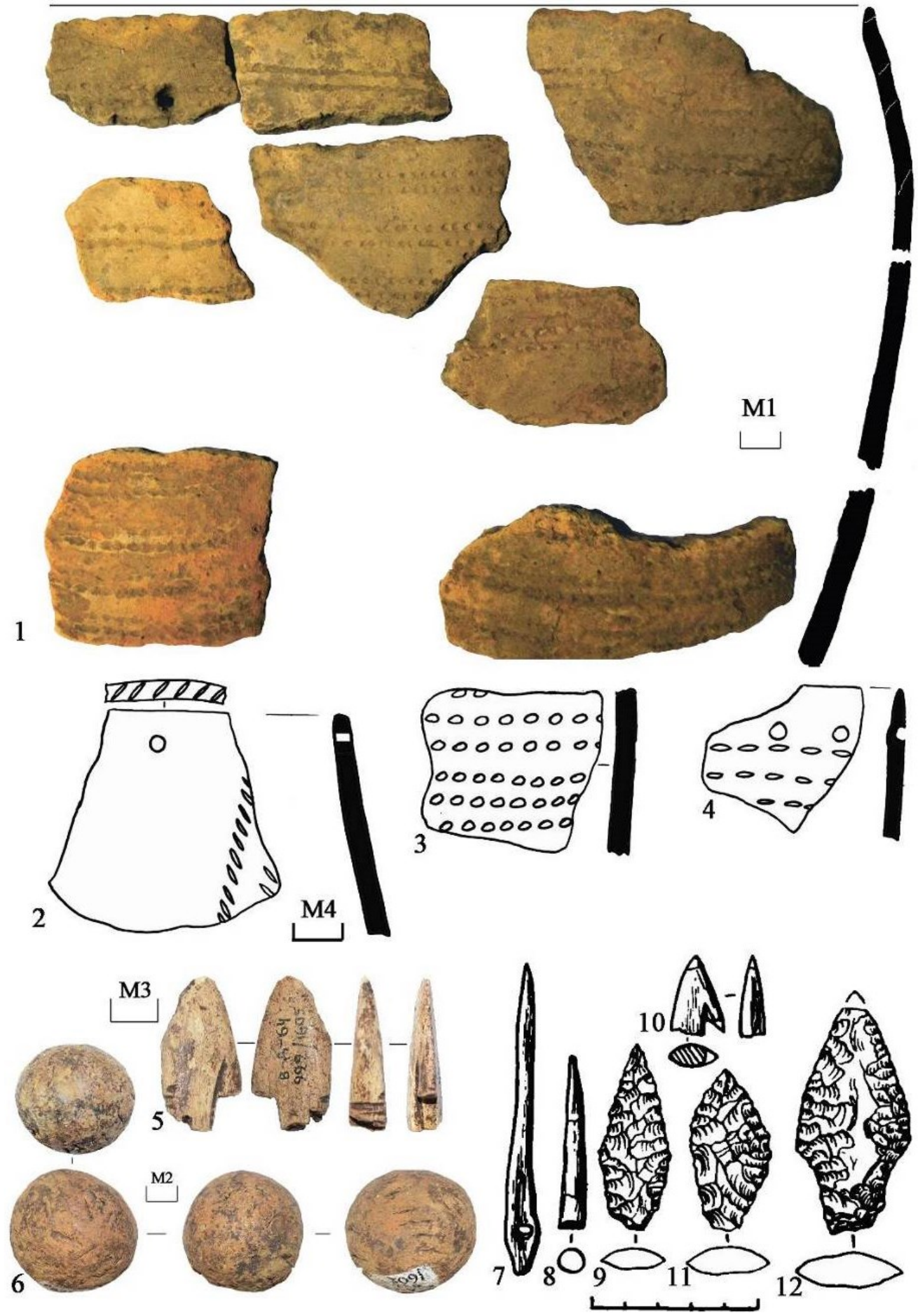

Рисунок 3 - стоянка Ярлуковская Протока (пункт 222). 1-4- керамика карамышевской культуры; 5 - глиняная игрушка-шарик раннего неолита; 6-8, 10- изделия из кости;

9, 11, 12- каменные наконечники стрел и дротиков. (7-12- материалы из публикации В.П. Левенка [6, с. 117])

Мы проанализировали фрагменты 15 горшков среднедонской культуры. ИПС для изготовления данной посуды была средне или слабозапесоченная илистая глина. Выявлено, что 2 образца были изготовлены из неожелезнённого и 13 из ожелезнённого сырья. В изломах, в малозначительной концентрации выявлены органические включения в виде полостей от выгоревших растений и водорослей, различных по размеру и форме (рис. 7: 5-6). В образцах средней запесоченности встречается кварцевый, окатанный песок размером 0,2-0,4 мм, имеющий концентрацию $1: 7-1: 8$, в единичной концентрации встречался до 1 мм (рис. 7: 4, 6). В 5 образцах обнаружены твёрдые округлой формы железистые частицы диаметром до 4 мм (рис. 7: 5). Сырьё среднедонских сосудов было использовано в естественном увлажненном состоянии, никаких признаков дробления не зафиксироваHo. 


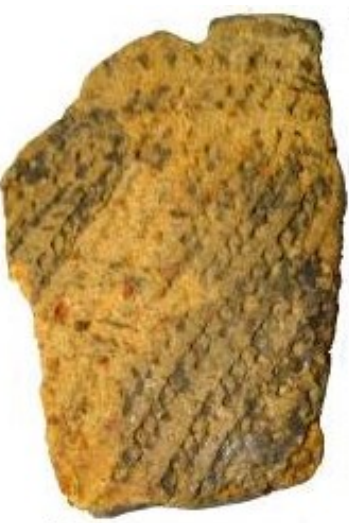

1

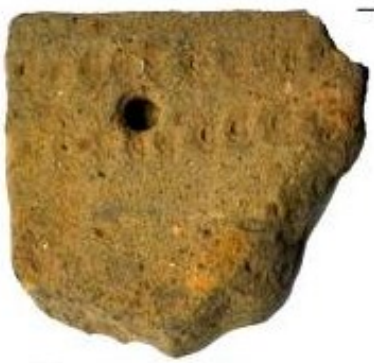

5

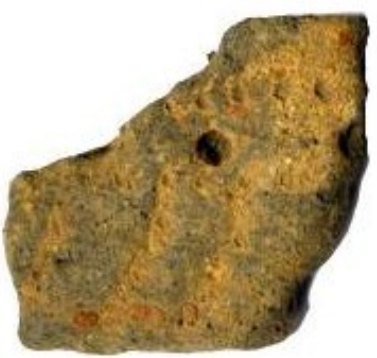

8

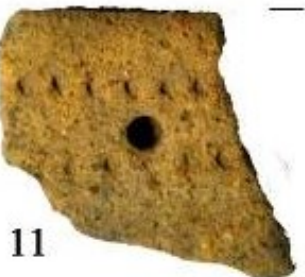

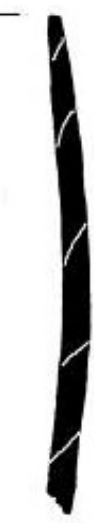

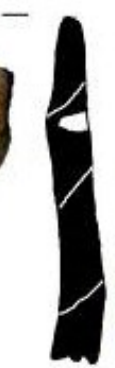

6

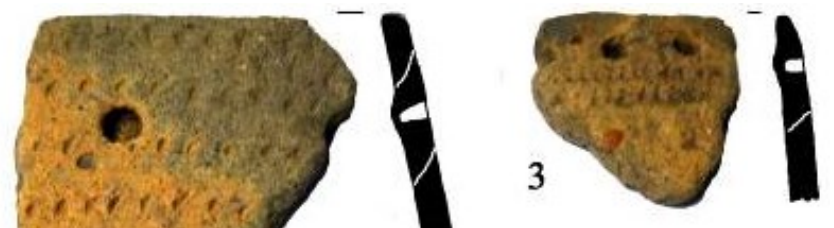

2
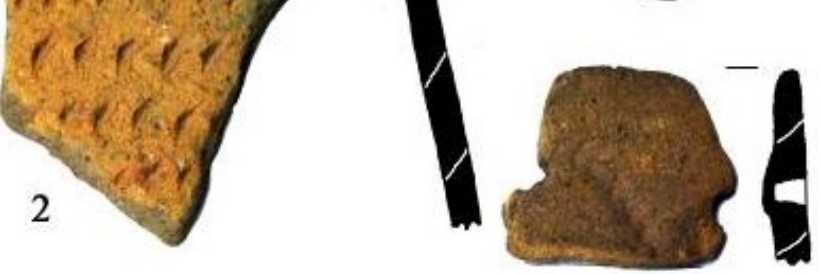

4

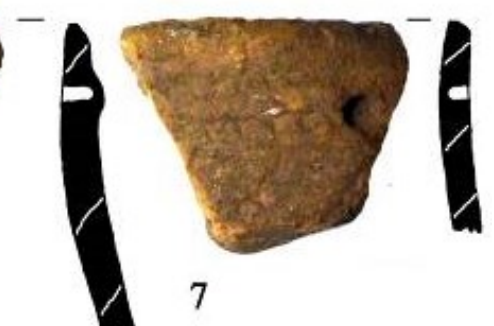

7
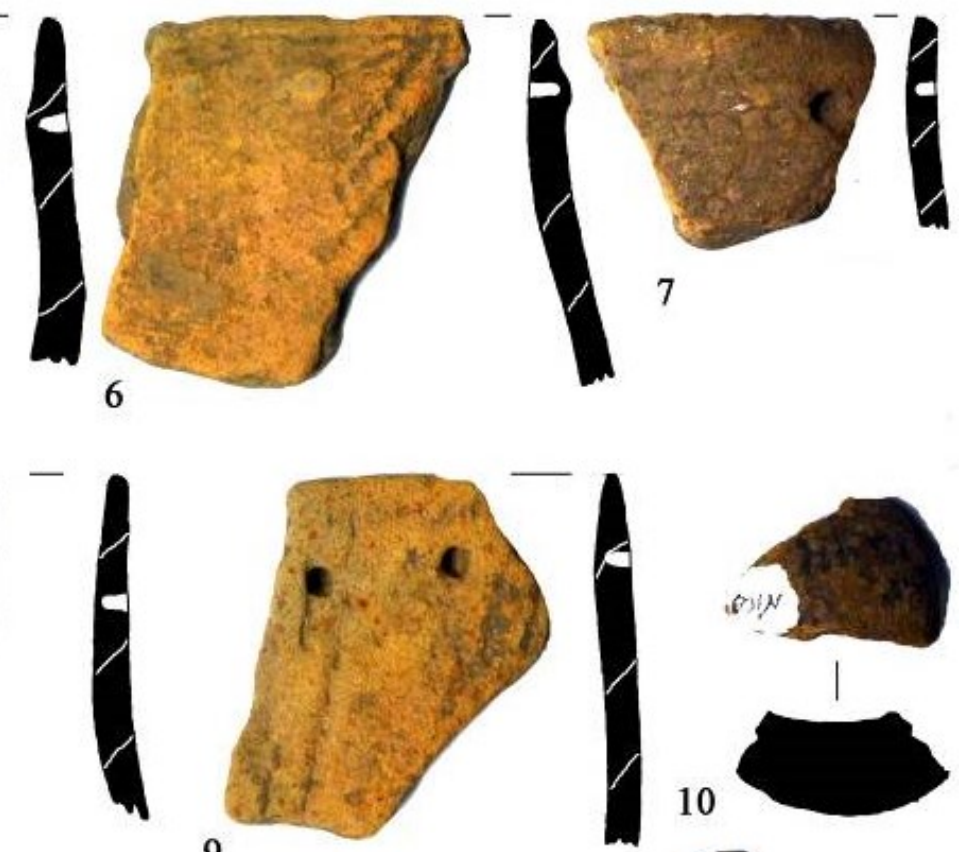

9
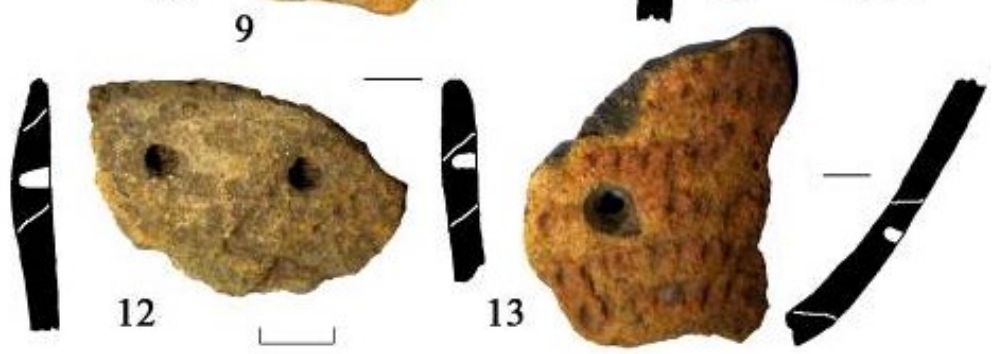

Рисунок 4 - Стоянка Ярлуковская Протока (пункт 222). 1-13- керамика среднедонской культуры

Механическая прочность сосудов средняя. Окраска изломов керамических фрагментов двух (9 обр.) или трёхслойная (6 обр.). При изготовлении данной керамики мы можем предположить использование кострового обжига. При этом отметим непродолжительную выдержку при температурах каления 650$700^{\circ} \mathrm{C}$, и равномерное повышение и дальнейшее снижение температур, что сказалось на однородной толщине слоёв.

Выявлены лишь общие признаки конструирования сосудов, которые изготавливались из небольших лоскутков размером от $1 \times 1$ до $2 \times 2 \mathrm{~cm}$, накладывавшихся по горизонтальной траектории. Выявлено три способа обработки поверхностей: 1 - внешняя тщательно заглажена грубо выделанной кожей, внутренняя расчёсана жёстким гребенчатым штампом (4 обр.); 2 - обе поверхности тщательно заглажены грубо выделанной кожей (1 обр.); 3 - обе поверхности расчёсаны жёстким гребенчатым штампом (10 обр.).
На момент исследования коллекции стоянки Ярлуковская Протока (пункт 222) обнаружено 304 единицы каменных артефакта. В публикации В.П. Левенка [6, с. 117] 1967 года были также встречены: два наконечника ромбовидной формы с выделенным обломанным черешком (рис. 1: 9, 12); один наконечник листовидной формы (рис. 1: 11); в единичных экземплярах отмечены: костяная игла (рис. 1: 7), острие (рис. 1: 8) и обломок гарпуна с одним клювовидным зубцом (рис. 1: 10). В качестве сырья использовался в основном цветной кремень низкого качества, в меньшем количестве использовался кварцит и другие породы.

Выявлено 6 экземпляров нуклеусов, из которых два одноплощадочных клиновидной формы (рис. 1: 2), остальные аморфные (рис. 1: 14). На трех экземплярах отмечена сильная сработанность, подобная ситуация характерна для памятников, удаленных от источников сырья. Все они были направлены на получение отщепов, только один использовался для снятия пластин (рис. 1:21). 


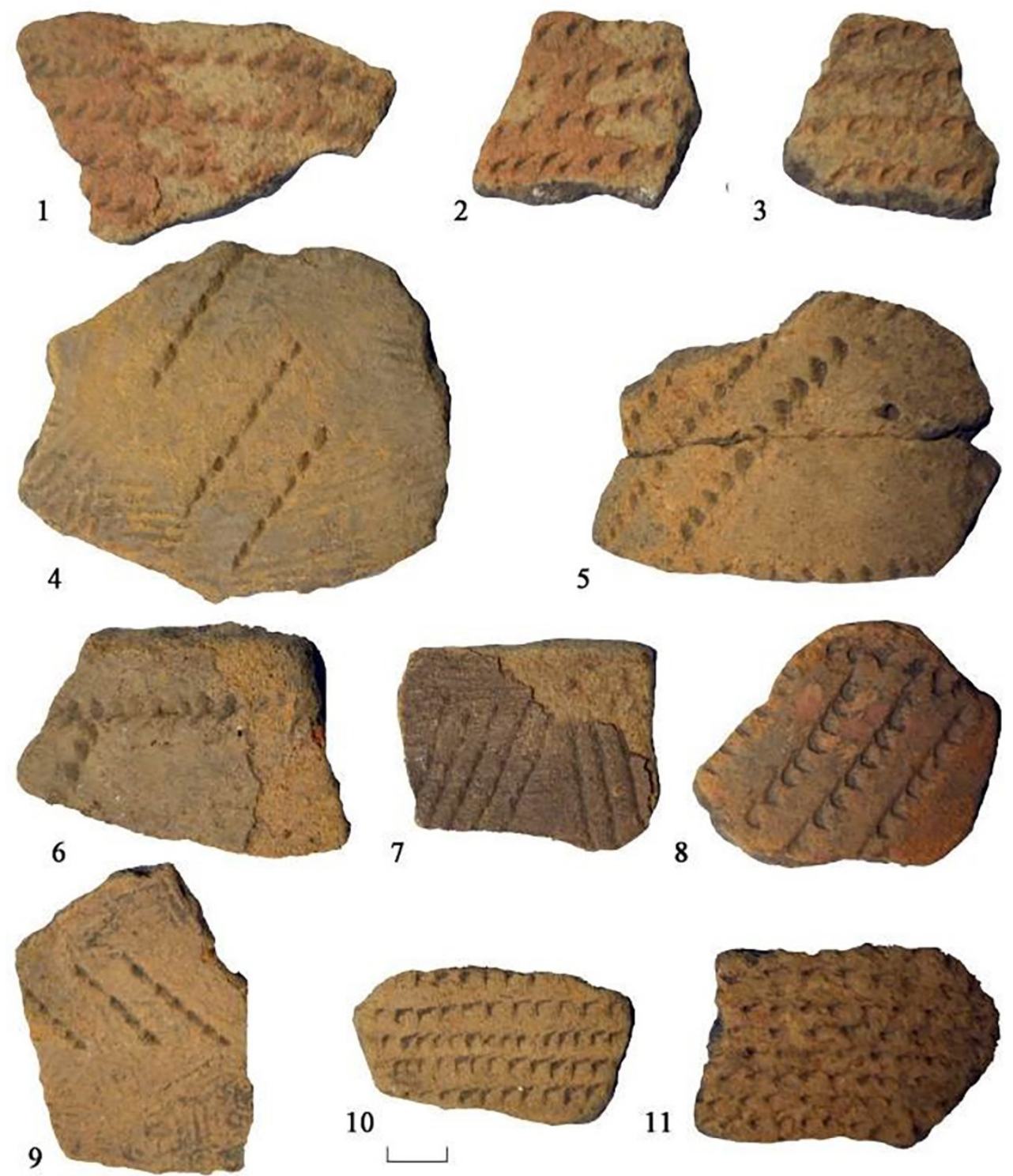

Рисунок 5 - Стоянка Ярлуковская Протока (пункт 222). 1-11- керамика среднедонской культуры

Каменная индустрия может быть охарактеризована как отщепово-пластинчатая. В коллекции отмечено 10 пластин, две из которых кварцитовые (рис. 1: 18), остальные миниатюрные из черного качественного кремня. Схожая картина отмечена и на других памятниках на Верхнем Дону, преобладающая часть пластин из черного высококачественного мелового кремня неместного происхождения и имеет миниатюрные размеры, тогда как кварцитовые пластины наоборот крупные или средние по величине.

Всего обнаружено 34 орудия, кроме одного, все они изготовлены на отщепах различных размеров, из них 16 представлены обломками типологически неопределимых орудий. Скребков выявлено 4 экземпляра различного типа: три концевых скребка с выпуклым округлым рабочим краем - два с ретушью по 2/3 изделия (рис. 1: 11, 12) и один с ретушью по сохранившейся кромке (рис. 1: 5); один концевой со скошенным выпуклым рабочим краем (рис. 1: 7).

Типологически выделяемых нами ножей выявлено два экземпляра: один на обломанной пластине (рис. 1: 10) и один на крупной отщепе с коркой (рис. 1: 9) с приостряющей ретушью по краям. Обнаружена пара скобелей с двумя узкими выемками (рис. 1: 16). В единичном экземпляре представлены: резец на кремневом отщепе (рис. 1: 17), перфора- тор/проколка срединного типа на отщепе (рис. 1: 13), тесло с частичной прошлифовкой поверхности (рис. 1: б). Обнаружено также три фрагмента изделий со следами шлифовки, на одном из них отмечена забитость, что также может указывать о возможном применении его в качестве отбойника (рис. 1: 15). На отдельно взятых экземплярах отходов производств были визуально отмечены следы шлифования и термической обработки.

В.П. Левенком в 1967 году отмечается находка так называемого «челнока» из мягкого глинистого сланца. Он считал, что такие предметы неизвестны среди материалов неолитических поселений ВолгоОкского междуречья, но имеют широкое распространение на Украине и на Урале [6, с. 119].

Кроме того, обнаружено пять полифункциональных орудий, сочетавших в себе несколько рабочих функций: концевой скребок-нож (рис. 1: 20) на первичном сколе; кварцитовый скребок-скобель с двумя выемками (рис. 1: 19); концевой полукруглый скребок-скобель с одной широкой выемкой (рис. 1: 8); кремневый скребок-скобель с двумя выемками, на котором визуально прослеживаются следы термического воздействия (рис. 1: 4); серединный резец-скребок концевой с выпуклым лезвием и жальцем (рис. 1: 3). 
Отметим, что единичные типы орудий находят аналогии на памятниках с материалами среднедонской ранненеолитической культуры на Верхних Дону и на памятниках елшанской культуры лесостепного Поволжья $[14$, с. 60$]$. Поселение является в некоторой степени смешанным комплексом, поэтому чётких стратиграфических и планиграфических наблюдений залегания каменного инвентаря сделать не удалось.
Материалы раннего неолита стоянки Ярлуковская Протока..

Остеологическая коллекция представлена несколькими десятками неопределимых кальцинированных костей. Обнаружен в музейной коллекции только один фрагмент орудия - острия (рис. 3: б). Всеволод Протасьевич указывается на известное значение рыболовства и собирательства, что подтверждается находками гарпунов, костей рыб, скорлупы орехов и обуглившихся желудей [6, с. 120].
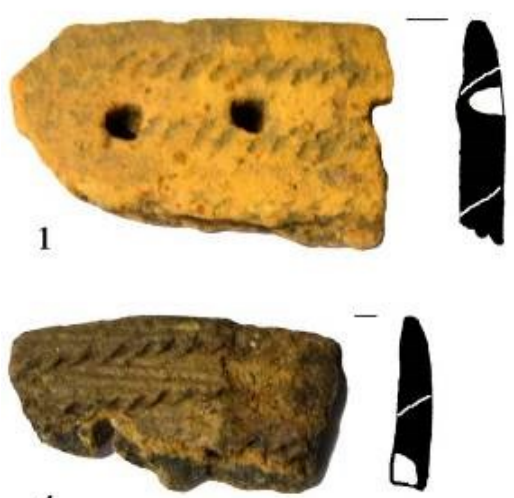

4

2
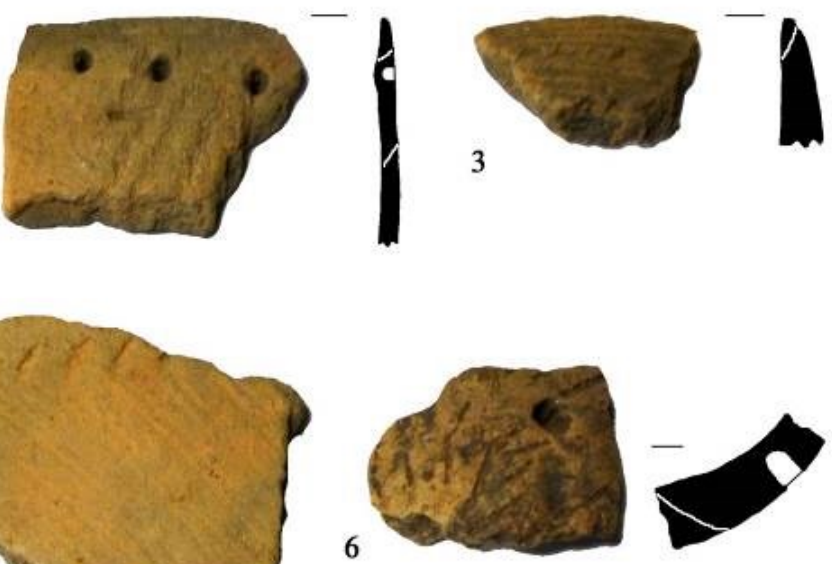

8
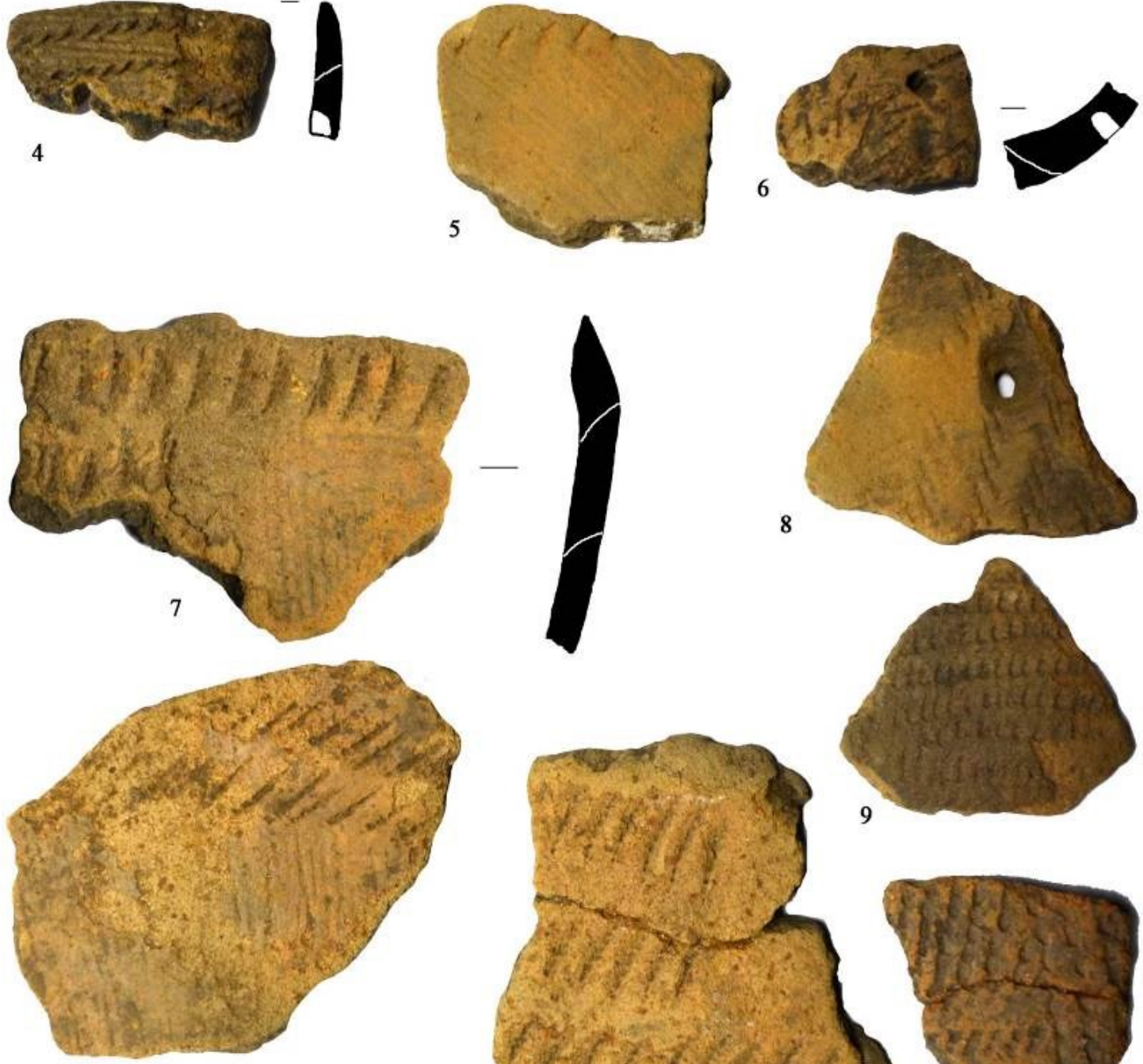

10

11

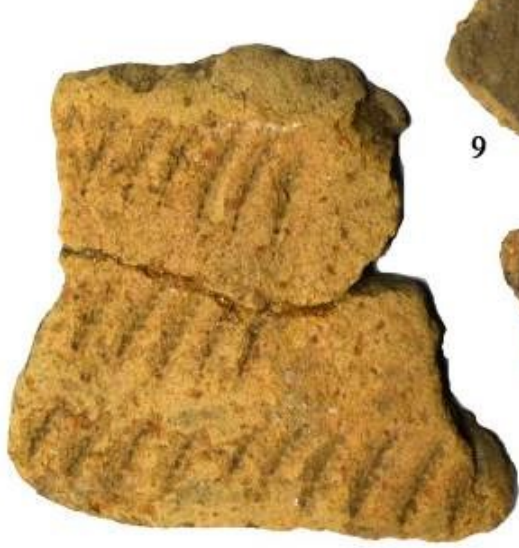

9

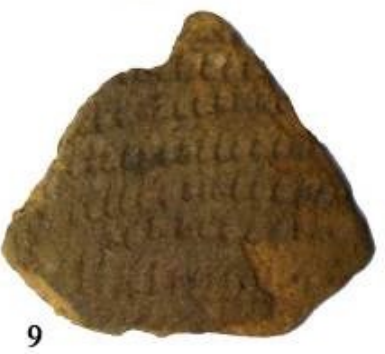

12

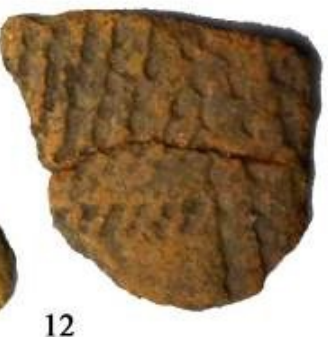

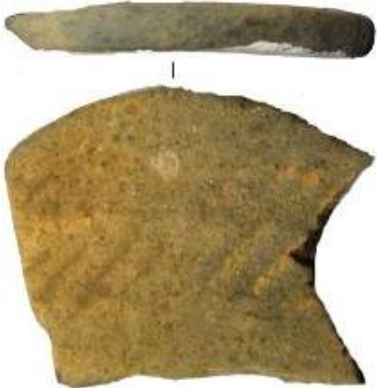

13

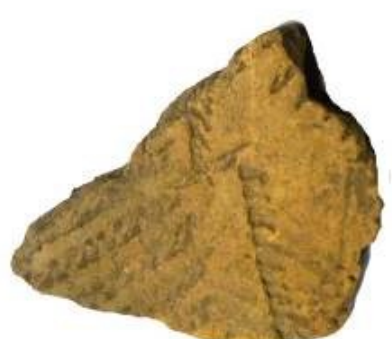

14

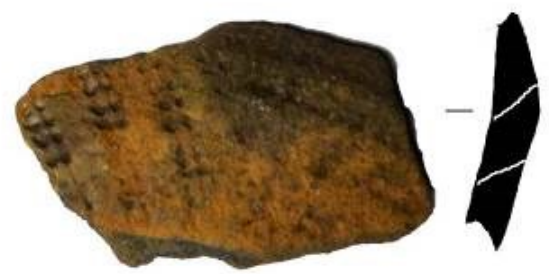

15

Рисунок 6 - Стоянка Ярлуковская Протока (пункт 222).

1-15- керамика среднедонской культуры; 13- керамический абразив 

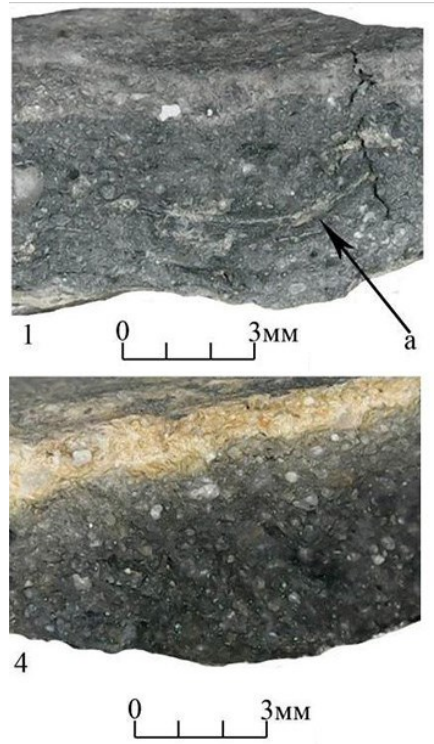
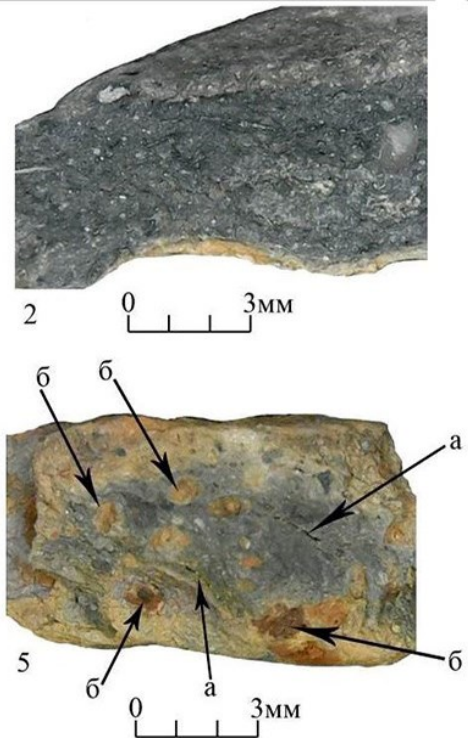
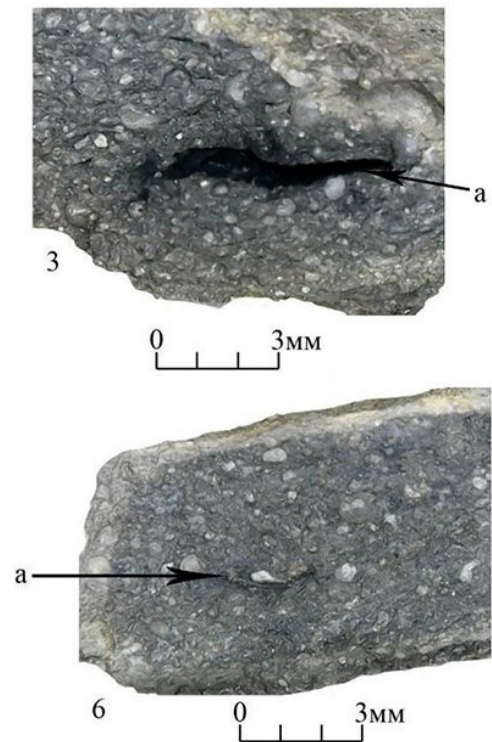

Рисунок 7 - Стоянка Ярлуковская Протока (пункт 222). Микроснимки изломов керамики. 1-3- елшанская культура; 4-6- среднедонская культура:

$a$ - полости от выгоревшей растительности; 6 - железистые частицы

Материалы исследованной стоянки считаются древнейшими на Верхнем Дону. По нашему мнению, приемы изготовления керамической посуды на территории Верхнего Дона сформировались при участии населения елшанской культуры. Оно пришло в Донской бассейн на рубеже VII-VI тыс. до н.э., при этом, уже имев опыт изготовления керамики. Местное население быстро осваивает готовый рецепт её изготовления. Именно поэтому мы фиксируем формирование навыка керамического производства ранненеолитических среднедонской и карамышевской культур за короткий промежуток времени. Это объясняет и то, что наиболее ранняя керамика среднедонской неолитической культуры Верхнего Дона со стоянки Ярлуковская Протока украшена раздельными наколами треугольной формы и имеет сходство с елшанским керамическим комплексом. В данной керамической коллекции имеются горшки с профилировкой. Сосуды лепились из схожего ИПС по аналогичной технологии. Единственным отличием является метод изготовления сосудов, отказ от лощения поверхности снаружи, появление гребенчатых сглаживающих расчёсов и отличительная система накольчатой орнаментации. По всей видимости, эта поселение заселялась населением среднедонской культуры на различных этапах развития. Подтверждает древность елшанской керамики и то, что материалы среднедонской неолитической культуры стратиграфически располагаются от третьего до седьмого горизонта, а посуда елшанкой культуры происходит из седьмого и шестого слоёв. По ранней накольчатой керамике среднедонской культуры получена дата - $6774 \pm 120$ $\mathrm{BP}$, или 5903-5484 ВC (SPb-1637). По поздней гребенчатой керамике среднедонской культуры получена дата $-5770 \pm 200$ или 5207-4246 ВC (SPB-1288) [15]. Накольчатая коллекция посуды этой стоянки практически полностью аналогична керамике стоянок Доброе 4, 7, 9 в верховьях р. Воронеж [16-18]. Со стоянки Доброе 4 [19] получена близкая радиоуглеродная дата $6912 \pm 120$ BP (6019-5621 cal BC) (SPb-1287).

\section{Список литературы:}

1. Левенок В.П. Отчет о полевых работах ВерхнеДонской археологической экспедиции Ленинградского отделения Института археологии Академии наук СССР и Липецкого областного краеведческого музея в 1963 г. // Архив ИА РАН. Р-1. № 2812, 2812а.

2. Левенок В.П. Отчет о полевых работах ВерхнеДонской археологической экспедиции Ленинградского отделения Института археологии Академии наук СССР и Липецкого областного краеведческого музея в 1964 г. // Архив ИА РАН. Р-1. 2943, 2943а.

3. Левенок В.П. Отчет о полевых работах ВерхнеДонской археологической экспедиции Ленинградского отделения Института археологии Академии наук СССР и Липецкого областного краеведческого музея в 1967 г. // Архив ИА РАН. Р-1. № 3613, 3613а.

4. Левенок В.П. Отчет о полевых работах ВерхнеДонской археологической экспедиции Ленинградского отделения Института археологии Академии наук СССР и Липецкого областного краеведческого музея в 1968 г. // Архив ИА РАН. Р-1. № 4002, 4002а.

5. Левенок В.П. Неолит Верхнего Дона и его место среди неолитических культур лесостепной зоны европейской части СССР: автореф. дис. ... канд. ист. наук. Л., 1969. 19 с.

6. Левенок В.П. Неолитические поселения на p. Матыре под Липецком // Краткие сообщения Института археологии. Вып. 111. М.: Наука, 1967. C. $116-120$.

7. Левенок В.П. Памятники днепро-донецкой культуры в лесостепной полосе РСФСР // Краткие сообщения Института археологии. Вып. 126. М.: Наука, 1971. C. 108-114.

8. Левенок В.П. Неолитические племена лесостепной зоны Европейской части СССР // Материалы и исследования по археологии СССР. № 172. М.: Наука, 1973. С. 185-197.

9. Смольянинов Р.В. Памятники елшанской культуры на Верхнем Дону // Археология Восточноевропейской Лесостепи. Вып. 2. Т. 1. Пенза: Копи-Ризо, 2008. C. 89-95.

10. Смольянинов Р.В., Наумова Т.В. Памятники верхневолжской культуры на Верхнем Дону // Археологические памятники Восточной Европы. Воронеж: Научная книга, 2009. С. 37-42.

11. Smolyaninov R., Skorobogatov A., Surkov A. Chronology of Neolithic sites in the forest steppe area of the Don River // Documenta Praehistorica. 2017. XLIV. P. 192-202. 
12. Бобринский А.А. Гончарство Восточной Европы. Источники и методы изучения. М.: Наука, $1978.272 \mathrm{c}$

13. Бобринский А.А. Гончарная технология как объект историко-культурного изучения // Актуальные проблемы изучения древнего гончарства: кол. монография. Самара: СамГПУ, 1999. С. 5-109.

14. Андреев К.М., Выборнов А.А. Ранний неолит лесостепного Поволжья. Самара: ООО «ПортоПринт», 2017. 272 с.

15. Радиоуглеродная хронология эпохи неолита Восточной Европы VII-III тысячелетия до н.э.: кол. моногр. / сост. Г.И. Зайцева, О.В. Лозовская, А.А. Выборнов, А.Н. Мазуркевич. Смоленск: Изд-во Свиток, 2016. $456 \mathrm{c}$

16. Смольянинов Р.В. Ранний неолит Верхнего Дона (по данным керамических комплексов): автореф. дис. ... канд. ист. наук. СПб., 2009. 314 с.

17. Куличков А.А., Скоробогатов А.М., Юркина Е.С., Смольянинов Р.В. Разведочные исследования в Добровском районе Липецкой области в 2017 году (по материалам поселения Доброе 7) // Ар- хеология восточноевропейской лесостепи: сб. матлов междунар. науч.-практ. конф., посв. 80-летию со дня рожд. А.Г. Николаенко (г. Белгород, 14-16 декабря 2017 года) / отв. ред. В.А. Сарапулкин. Белгород: ИД «Белгород» НИУ «БелГУ», 2018. С. 56-78.

18. Смольянинов Р.В., Куличков А.А., Юркина Е.С. Стоянка среднедонской культуры Доброе 9 на Верхнем Дону // XXI Уральское археологическое совещание, посв. 85-летию со дня рожд. Г.И. Матвеевой и 70-летию со дня рожд. И.Б. Васильева: мат-лы всерос. науч. конф. с междунар. участием. Самара: Издво СГСПУ, 2018. С. 67-71.

19. Смольянинов Р.В., Куличков А.А., Клоков А.Ю. Керамика с поселения Доброе 4 (пункт 385) на Верхнем Дону // Тверской археологический сборник. Вып. 11. Тверь: Изд-во «Триада», 2018. С. 318-325.

Статья публикуется при поддержке гранта РФФИ проект 18-49-480004 р_а «Поселение Доброе 9 в системе ранненеолитических древностей лесостепного Подонья" и гранта Фонда президентских грантов.

\section{MATERIALS OF THE EARLY NEOLITHIC OF THE YARLUKOVSKAYA PROTOKA SITE (POINT 222) ON THE UPPER DON}

(C) 2019

Smolyaninov Roman Viktorovich, candidate of historical sciences, head of Archeology and Ethnology Office Lipetsk State Pedagogical P. Semenov-Tyan-Shansky University (Lipetsk, Russian Federation)

Kulichkov Aleksey Aleksandrovich, head of Local History Work Department Intersettlement Coordination and Methodological Center of Gryazinsky District of Lipetsk Region (Gryazi, Lipetsk Region, Russian Federation)

Yurkina Elizaveta Sergeevna, student of History, Law and Social Sciences Institute Lipetsk State Pedagogical P. Semenov-Tyan-Shansky University (Lipetsk, Russian Federation)

Abstract. This paper analyzes materials located in the floodplain of the Matyra River (left tributary of the Voronezh River) of the Yarlukovskaya Protoka (point 222) in the Gryazinsky District of the Lipetsk Region. It was investigated in 1963, 1964, 1967 and 1968 by Vsevolod Levenok. The materials of three early Neolithic cultures of VI Millennium BC were revealed here. The materials of the Yelshanskaya culture are represented by corollas and bottoms of 12 vessels. Almost all dishes, except one bottom and several walls, have no ornament, with the exception of one or two rows of conical pit. All ceramics are well smoothed. Ceramics were made from silty clay. The location of materials in the cultural layer confirms the earlier occurrence of the Yelshanskaya culture ceramics. The ceramics of the Karamyshevo culture is represented by fragments from three vessels. The dishes are predominantly decorated with small oval pricks composed in horizontal and vertical rows. Ceramics were made from silty clay. Ceramics of the Srednedonskaya culture are represented by corollas and rounded bottoms of 15 vessels. It is decorated with triangular prick or small comb prints. Ceramics were made from silty clay. At Yarlukovskaya Protoka site 304 stone artifacts were discovered, mainly of flint. This industry could be described as flake-blade technique. The monument is a mixed complex - stratigraphic and planigraphic readable observations of stone inventory location could not be done.

Keywords: Upper Don; forest-steppe; Early Neolithic; ceramics; temper; radiocarbon dating; flint; Srednedonskaya Neolithic culture; Karamyshevo Neolithic culture; Yelshanskaya Neolithic culture; prick; comb ornament; tool; flake; scraper; knife; polyfunctional tools; blade; core; typological analysis.

УДК 902

DOI 10.24411/2309-4370-2019-12219

Статья поступила в редакцию 24.01.2019

\section{СООТНОШЕНИЕ НЕОЛИТИЧЕСКИХ И ЭНЕОЛИТИЧЕСКИХ КОМПЛЕКСОВ ЛЕСОСТЕПНОГО ПОВОЛЖЬЯ ПО ДАННЫМ РАДИОУГЛЕРОДНОГО ДАТИРОВАНИЯ}

Сомов Анатолий Владимирович, магистрант кафедры отечественной истории и археологии, лаборант научно-исследовательской части

Шалапинин Антон Александрович, кандидат исторических наук, научный сотрудник научно-исследовательской части

Самарский государственный соџчильно-педагогический университет (2. Самара, Российская Федераџия)

Аннотация. В статье приведена база данных радиоуглеродного датирования, которая была получена по средневолжской археологической культуре развитого и позднего неолита, а также по энеолитическим материалам лесостепного Поволжья. Ключевым вопросом является хронологическое соотношение данных ком- 